\title{
Playful Rehabilitation with Playware for Older Adults Keynote
}

\section{Lund, Henrik Hautop}

\section{Published in:}

Gerontechnology

Link to article, DOI:

10.4017/gt.2014.13.02.215.00

Publication date:

2014

\section{Document Version}

Publisher's PDF, also known as Version of record

Link back to DTU Orbit

Citation (APA):

Lund, H. H. (2014). Playful Rehabilitation with Playware for Older Adults: Keynote. Gerontechnology, 13(2), 69. https://doi.org/10.4017/gt.2014.13.02.215.00

\section{General rights}

Copyright and moral rights for the publications made accessible in the public portal are retained by the authors and/or other copyright owners and it is a condition of accessing publications that users recognise and abide by the legal requirements associated with these rights.

- Users may download and print one copy of any publication from the public portal for the purpose of private study or research.

- You may not further distribute the material or use it for any profit-making activity or commercial gain

- You may freely distribute the URL identifying the publication in the public portal

If you believe that this document breaches copyright please contact us providing details, and we will remove access to the work immediately and investigate your claim 


\section{Playful rehabilitation with playware for older adults}

H.H. LUND. Playful rehabilitation with playware for older adults (Keynote). Gerontechnology 2014; 13(2):69; doi:10.4017/gt.2014.13.02.215.00 Purpose We examine methods of play used by older adults and analyzed how play can be incorporated in playware defined as intelligent hardware and software that create play and playful experiences among users of all ages. We investigate how using playware improves the abilities of the elderly in many areas of high importance for activities of daily living, e.g. a broad range of abilities including mobility, agility, balancing, strength and endurance. Further, we explore how playware technology can be developed so that it can be used easily by anyone, anywhere, anytime. Method For interdisciplinary technological development of playware, we use a participatory approach characterized by rapid prototyping cycles, which allow iterative technology specification and development together with people in their own environments. The knowledge about intelligent technology from engineering and about play from the humanities is synthesized to develop design principles, prototypes, and demonstrators of playware technology. Several of these demonstrators are selected for (e.g. industrial) refinement to become modular playware technology products. The resulting modular playware technology is systematically studied and investigated in the messy real-world environments to guide the next cycle of synthesis, demonstrator and prototype development. Results \& Discussion The development of playware resulted in the Playware $\mathrm{ABC}$ concept: By building bodies and brains with the user-configurable modular system (e.g. modular playware tiles), the user can construct, combine and create to make solutions for anyone, anywhere, anytime. Studies with older adults (community-dwelling elderly, stroke patients, and cardiac patients ${ }^{1,2}$ ) playing with such playware showed that the technology can easily be used, and that playing with such modular playware has effects on a broad range of abilities including mobility, agility, balancing, strength and endurance. The studies show that it is possible to develop technological modules that any user can easily understand, and that the playful interaction seems to motivate the older adults to perform physical actions, which may prove beneficial to their health. Further, because the technology seems to motivate most users to play, the playware may also facilitate also intergenerational play.

\section{References}

1.Lund $\mathrm{HH}$, Jessen $\mathrm{J}$. Effects on community-dwelling elderly playing with modular interactive tiles. Proceedings of the International Conference on Serious Games and Edutainment. Heidelberg: Springer; 2012

2.Nielsen $\mathrm{CB}$, Lund $\mathrm{HH}$. Adapting Playware to Rehabilitation Practices. International Journal of Computer Science in Sport 2012;11(1):1-12

Keywords: work \& leisure, fun interactive technologies, playware, play, rehabilitation

Address: Center for Playware, Technical University of Denmark, Kgs. Lyngby, Denmark

E: hhl@playware.dtu.dk

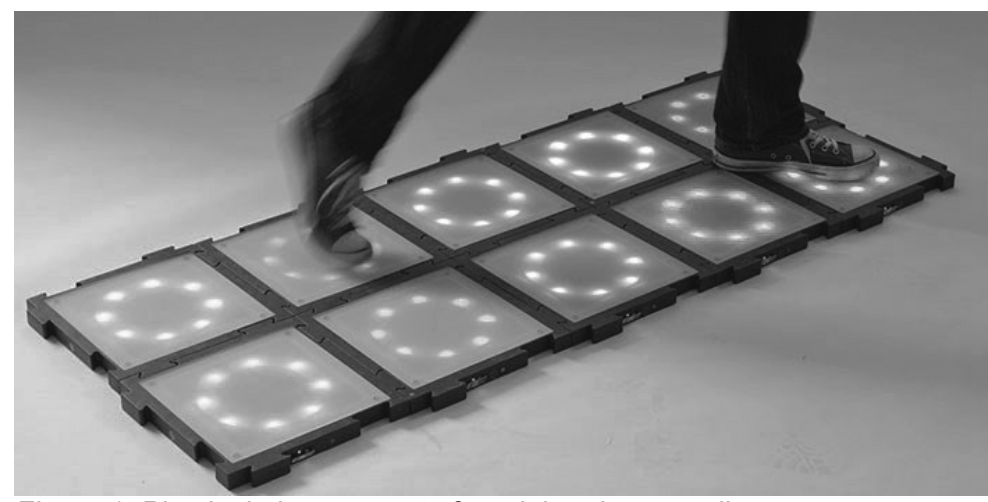

Figure 1. Physical play on a set of modular playware tiles 